\title{
Biolaitoksen sivutuotteena syntyvä nestemäinen ammoniumnitraatti, am- moniumsulfaatti ja urea kevätvehnän lannoitteena
}

\author{
Petri Kapuinen ja Tanja Ikäläinen \\ Luke, Uudet liiketoimintamahdollisuudet, 21500 Piikkiö, petri.kapuinen@luke.fi
}

\section{Tiivistelmä}

Lantaa ja lantapohjaisia orgaanisia lannoitevalmisteita saa käyttää vain 170 kg/ha kokonaistyppeä vastaavan määrän kalenterivuodessa ns. nitraattiasetuksen asettaman rajoituksen takia. Rajoituksella pyritään estämään pohjaveden nitraattipitoisuuden nousua epäterveelliseksi. Rajoitus ei koske muita lannoitevalmisteita. Rajoitus rajaa useiden kasvien lannasta tai lantapohjaisista lannoitevalmisteista tulevan liukoisen typen annoksen liian pieneksi täyden sadon saavuttamiseksi. Niistä tulevaa typpilannoitusta voidaan täydentää tavoitetasoon mineraalilannoitteilla. Täydennyslannoitus mineraalilannoitteilla on usein muutoinkin tarkoituksenmukaista, koska se takaa riittävän typen saannin kasvukauden alussa ja pienentää lannasta ja orgaanisista lannoitevalmisteista tulevan liukoisen typen annoksen vaihtelun hyväksyttävällä tasolle. Tämä vaihtelu johtuu niiden liukoisen typen pitoisuuden vaihtelusta ja levityksen epätasaisuudesta. Mineraalilannoitteiden typpi on yleensä otettu ilmakehästä hyödyntäen fossiilista energiaa. Sitä voidaan kuitenkin valmistaa myös kierrätysmateriaalista, kuten lannasta.

Kun lannasta erotetaan nesteosa ja siitä stripataan liukoista typpeä ammoniakkina ja pestään se edelleen rikki- tai typpihapolla saadaan epäorgaanista lannoitevalmisteeksi luettavaa ammoniumsulfaattia tai -nitraattia, jota ei ns. nitraattiasetuksen kokonaistypen annoksen rajoitus koske. Saatu lannoite on nestemäistä, mutta se voidaan myös rakeistaa. Rakeistamisesta syntyy kuitenkin lisäkustannuksia. Tilatason toimintana lannoite kannattaa käyttää nesteenä, koska logistiset kustannukset jäävät pieniksi, vaikka tuote ei olisikaan yhtä konsentroitua kuin rakeiset lannoitteet. Lisäksi nestemäiset lannoitteet voivat olla paremmin kasvien käytettävissä tai niiden levitys voi olla helpompaa. Lisäksi ne sopivat erityisesti kasvustolle annettavaan lisälannoitukseen.

Suomessa lannoitteet on kuitenkin perinteisesti käytetty rakeisena ja koneet on suunniteltu niiden levittämiseen. Nestemäisten lannoitteiden levitykseen kasvustoon sopivat kasvinsuojeluruiskut. Niillä ei kuitenkaan voida sijoittaa, mistä on erityistä etua Suomen lyhyessä kasvukaudessa. Amerikan Yhdysvalloissa nestemäisten typpilannoitteiden sijoittaminen on yleistä, ja heillä on käytössään siihen tarvittavat koneet.

Tässä tutkimuksessa selvitettiin lannasta potentiaalisesti valmistettavien lannoitteiden käyttöä kevätvehnän lannoituksessa kenttäkokeella vuonna 2014 Jokioisissa ja vuonna 2015 Kaarinassa. Tutkittavana oli nestemäisen ammoniumsulfaatin ja -nitraatin bulkkikäyttö kevätvehnäkasvuston perustamisen yhteydessä. Ammoniumsulfaattia ja -nitraattia myös sijoitettiin rakeisena kylvölannoittimella kylvön yhteydessä. Vuonna 2015 tutkittiin myös nestemäisen typpilannoitteen sijoittamista kylvön yhteydessä amerikkalaisvalmisteisella kylvölannoittimella. Tähkimisvaiheessa levitettiin edellisten lisäksi ureaa kasvinsuojeluruiskulla valkuaispitoisuuden nostamiseksi.

Tulosten perusteella perinteinen rakeinen mineraalilannoite sijoitettuna kylvölannoittimella on varsin hyvä ratkaisu. Muilla ratkaisulla voidaan saavuttaa lähes sama satotulos. Bulkkikäyttö ja rakeisen ammoniumsulfaatin käyttö saattaa olla perusteltua, jos tuote on edullista. Ammoniumsulfaatti ei näytä sopivan ainakaan laimentamatta valkuaispitoisuuden nostoon.

Asiasanat: typpi, ammoniumnitraatti, ammoniumsulfaatti, urea, lantapohjaiset lannoitevalmisteet, nitraattiasetus, kevätvehnä, lannoitus, nestemäiset lannoitteet, rakeiset lannoitteet, strippaus, suorakylvö 


\section{Johdanto}

Lanta ja raaka-aineissa lantaa yli 10 \% sisältäviä lannoitevalmisteita saa käyttää vain 170 kg/ha kokonaistyppeä (KN) vastaavan määrän kalenterivuodessa ns. nitraattiasetuksen (VN 2015) asettaman rajoituksen takia pohjaveden nitraattipitoisuuden nousun epäterveelliselle tasolle nousemista vastaan, mutta rajoitus ei koske muita orgaanisia lannoitevalmisteita. Rajoitus estää käyttämässä näitä tuotteita monilla kasveilla sellaisen määrän, että niistä saataisiin täysi sato. Koska rajoitus ei koske lannasta valmistettua epäorgaanista lannoitevalmistetta, valmistamalla ja käyttämällä niitä voidaan rajoitusta kiertää käyttämällä niitä ainakin täydennyslannoitteena. Epäorgaanisissa lannoissa on ravinnepitoisuudet vaihtelevat vähemmän kuin orgaanisissa ja niiden levitystasaisuus on parempi, jolloin niiden käyttö täydennyslannoitteena vähentää liukoisen typen (LN) annoksen vaihtelun hyväksyttävälle tasolle. Lannasta tai muusta orgaanisesta lannoitevalmisteesta saadusta rejektistä voidaan LN poistaa strippamalla $\mathrm{NH}_{3}$ :ksi ja pestä esimerkiksi rikkihapolla, jolloin saadaan epäorgaanista nestemäistä ammoniumsulfaattia (AS). Se voidaan edelleen kiteyttää, jolloin lannoitetta voidaan levittää perinteisillä mineraalilannoitteen levittimillä, kuten keskipakoislevittimillä ja kylvölannoittimilla. Nestemäinen lannoite voidaan levittää kasvinsuojeluruikulla tai erityisellä nestemäisten lannoitteiden sijoitukseen tarkoitetuilla kylvölannoittimilla.

Tämän tutkimuksen tavoitteena oli selvittää strippaustuotteiden soveltuvuus vehnän lannoitukseen nestemäisenä ja kiteytettynä.

\section{Aineisto ja menetelmät}

Kenttäkokeet perustettiin vuonna 2014 Jokioisiin (taulukko 1) vuonna 2015 Kaarinaan (taulukko 2). Vuonna 2015 pienennettiin AS:sta tulevan typen osuutta koejäsenessä, jossa sitä annettiin ennen kylvöä. Muuten vuosien yhteiset koejäsenet olivat samanlaiset, mutta vuoden 2015 kokeessa oli kuitenkin muutamia lisäkoejäseniä.

Taulukko 1. Koejäsenet 2014

\section{Koejäsen kg N/ha Typen muoto}

$\begin{array}{lc}\text { A1 } & 0 \text { Ammoniumnitraatti } \\ \text { A2 } & 30 \text { Ammoniumnitraatti } \\ \text { A3 } & 60 \text { Ammoniumnitraatti } \\ \text { A4 } & 90 \text { Ammoniumnitraatti } \\ \text { A5D1 } & 120 \text { Ammoniumnitraatti } \\ \text { A5D2 } & 120 \text { Ammoniumsulfaatti } \\ \text { A6 } & 150 \text { Ammoniumnitraatti } \\ \text { A7 } & 180 \text { Ammoniumnitraatti } \\ \text { B1D1 } & 120 \text { Kylvön yhteydessä sijoittamalla } 60 \mathrm{~kg} \mathrm{~N} / \mathrm{ha} \text { ammoniumnitraattia + kastelukannulla } \\ & 60 \text { kg N/ha ammoniumnitraattia } \\ \text { B1D2 } & 120 \text { Kylvön yhteydessä sijoittamalla } 60 \mathrm{~kg} \text { N/ha ammoniumnitraattia + kastelukannulla } \\ & 60 \text { kg N/ha ammoniumsulfaattia } \\ \text { B2D1 } & 135 \text { Kylvön yhteydessä } 120 \mathrm{~kg} \text { N/ha ammoniumnitraattia }+15 \mathrm{~kg} \text { N/ha } \\ & \text { ammoniumnitraattia ruiskuttamalla tähkälle } \\ \text { B2D2 } & 135 \text { Kylvön yhteydessä } 120 \mathrm{~kg} \text { N/ha ammoniumnitraattia }+15 \mathrm{~kg} \text { N/ha } \\ & \text { ammoniumsulfaattia ruiskuttamalla tähkälle }\end{array}$

Jokioisten Ojaisten koekenttä oli 14.5.2014 otettujen näytteiden mukaan aistinvaraisen arvion perusteella multavaa hietasavea. Sen johtoluku oli $10 \mathrm{x}$ mS/cm, pH 6,0 (tyydyttävä), fosfori 4,4 (välttävä), kalium 196 (välttävä), kalsium 2340 (tyydyttävä), magnesium 659 (korkea) ja rikki 8,5 (välttävä). Yltöisten koekenttä oli 8.6.2105 otettujen näytteiden mukaan mekaanisella maalajianalyysilla määritettynä hietasavea (saves 51,2 \%, hiesu 19,7 \%, hieta ja karkeammat 21,1\%).

Molempina vuosina koekasvina oli saman erän Wellamo -kevätvehnä $\left(650 \mathrm{kpl} / \mathrm{m}^{2}\right.$, hlp 32,8, itävyys 96 \% => kylvömäärä 222 kg/ha). Koealueet perustettiin 2014 22.5.2014 ja 8.-9.6. 2015 Vuo- 
den 2015 perustaminen oli varsin myöhään toukokuun sateiden takia. Koemuotona oli periaatteessa satunnaistettujen lohkojen koe, jossa neljä lohkoa. Ensimmäisenä satunnaistettiin lohkojen sisällä varsinaisten koejäsenten ja typpitasojen puolet, sitten typpitasot keskenään ja koejäsenet keskenään (taulukot 1 ja 2). Varsinaisista ennen kylvöä annettujen lannoitteiden käsittelyt olivat omana pääruutunaan, nestemäisen lannoitteen sijoituskäsittelyt omanaan (vuosi 2015) ja tähkimisvaiheessa tehdyt käsittelyt omanaan.

Taulukko 2. Koejäsenet 2015

\begin{tabular}{|c|c|}
\hline Koejäsen & Typen muoto \\
\hline A1 & 0 Ammoniumnitraatti \\
\hline A2 & 30 Ammoniumnitraatti \\
\hline A3 & 60 Ammoniumnitraatti \\
\hline A4 & 90 Ammoniumnitraatti \\
\hline A5D1 & 120 Ammoniumnitraatti \\
\hline A5D2 & 120 Ammoniumsulfaatti \\
\hline A6 & 150 Ammoniumnitraatti \\
\hline A7 & 180 Ammoniumnitraatti \\
\hline B1D1 & $\begin{array}{l}120 \text { Kylvön yhteydessä sijoittamalla } 60 \text { kg N/ha ammoniumnitraattia + kastelukannulla } \\
60 \text { kg N/ha ammoniumnitraattia }\end{array}$ \\
\hline B1D2 & $\begin{array}{l}120 \text { Kylvön yhteydessä sijoittamalla } 100 \text { kg N/ha ammoniumnitraattia + kastelukannulla } \\
20 \text { kg N/ha ammoniumnitraattia }\end{array}$ \\
\hline B1D3 & $\begin{array}{l}120 \text { Kylvön yhteydessä sijoittamalla } 100 \text { kg N/ha ammoniumnitraattia + kastelukannulla } \\
20 \text { kg N/ha ammoniumsulfaattia }\end{array}$ \\
\hline B2D1 & $\begin{array}{l}85 \text { Kylvön yhteydessä sijoittamalla seos } 65 \text { kg N/ha urea-ammoniumnitraattia + } 20 \text { kg } \\
\text { N/ha nestemäistä ammoniumsulfaattia (GreatPlains) }\end{array}$ \\
\hline B2D2 & $\begin{array}{l}90 \text { Kylvön yhteydessä sijoittamalla } 90 \text { kg N/ha rakeista ammoniumnitraattia } \\
\text { (GreatPlains) }\end{array}$ \\
\hline B3D1 & $\begin{array}{l}135 \text { Kylvön yhteydessä } 120 \text { kg N/ha ammoniumnitraattia + } 15 \text { kg N/ha } \\
\text { ammoniumnitraattia ruiskuttamalla tähkälle }\end{array}$ \\
\hline B3D2 & $\begin{array}{l}135 \text { Kylvön yhteydessä } 120 \mathrm{~kg} \text { N/ha ammoniumnitraattia + } 15 \text { kg N/ha } \\
\text { ammoniumsulfaattia ruiskuttamalla tähkälle }\end{array}$ \\
\hline B3D3 & $\begin{array}{l}135 \text { Kylvön yhteydessä } 120 \mathrm{~kg} \mathrm{~N} / \mathrm{ha} \text { ammoniumnitraattia + } 15 \mathrm{~kg} \text { N/ha ureaa } \\
\text { ruiskuttamalla tähkälle }\end{array}$ \\
\hline
\end{tabular}

Vuoden 2014 koekenttä Jokioisten Ojaisilla oli kevytmuokattu syksyllä 2013. Vuoden 2015 koekenttä Yltöisissä oli muokattu Tume -lautasmuokkaimella syksyllä 2014. Koeruudut kylvömuokattiin vaakatasojyrsimellä perinteiden kylvötavan vaatimusten mukaisesti poikki koeruutujen.

Koekäsittelyyn liittyvät ennen kylvöä tehtävät levitykset toteutettiin ennen kylvö. Noin tunti näiden levitysten jälkeen asianomaisten käsittelyiden koeruudut äestettiin joustopiikkiäkeellä kertaalleen levitettyjen lannoitevalmisteiden multaamiseksi. Tätä seurasi kylvö viimeistään seuraavana päivänä. Koeruudut kylvettiin kumpanakin kenttäkoevuonna samalla Tume KL 2500 kylvölannoittimella paitsi vuonna 2015 asianomaiset kaksi koejäsentä (taulukko 2) Great Plains 1500 suorakylvölannoittimella, joka oli varustettu nestelannoitusvarustuksella. Kylvömuokkaus Yltöisissä vuonna 2015 perinteisen kylvötavan vaatimusten mukaisesti ei ole ollut eduksi suorakylvökone - käsittelyille, koska siemenet ja lannoite jäivät muokkauskerrokseen eikä sen pohjalle. Käytännössä oli kuitenkin mahdotonta jättää nämä koeruudut muiden välistä kylvömuokkaamatta vaakatasojyrsimellä. Perustamisen jälkeen satoi kuitenkin runsaasti ja usein, joten haitta suorakylvötavalle ei ollut yhtä merkittävä kuin tavanomaisempana vuonna, vaikka vehnä orastuikin suorakylvöruuduissa myöhemmin kuin muissa ruuduissa. Suorakylvökoneella perustettiin myös verranneruutu varsinaisen koejäsen viereen, jonka tuloksia voidaan verrata vastaavalla typpitasolla perinteisellä kylvölannoittimella perus- 
tettuun typpitasoon ja poistaa koneen, kylvötavan ja yhden päivän eron perustamisajassa vaikutus satotuloksista. Nestemäisen lannoitteen sijoitus otettiin kokeeseen mukaan, koska Suomen kasvukaudessa kylvölannoitustekniikasta on oleellista etua muun muassa viljakasvien N:n saannissa kasvukauden alussa. N-puute kasvukauden alussa johtaa vääjäämättä sadon menetyksiin. Kylvölannoitustekniikan käyttö on erityisen oleellinen silloin, kun koko N-annos halutaan antaa nestemäisenä. Lisäksi erillinen nestemäisen lannoitteen levitys lisää kustannuksia.

Vuonna 2014 kokeessa ennen kylvöä tehdyt letkulevitystä imitoivat nestemäisen ammoniumnitraatin (AN) ja -sulfaatin (AS) levityksen typpimäärä oli $60 \mathrm{~kg} \mathrm{~N} / \mathrm{ha}$ (taulukko 1). Se täydennettiin kylvölannoituksen yhteydessä sijoittamalla rakeista AN:a niin, että N:n yhteismäärä oli $120 \mathrm{~kg} / \mathrm{ha}$, joten kylvön yhteydessä sijoitettiin $60 \mathrm{~kg}$ N/ha. Ennen kylvöä AS: a saaneet koejäsenet saivat huomattavan S-annoksen (69 kg S/ha) AS:n mukana. N-tasojen mukana ollut käsittely rakeisella AS:lla sai huomattavan S-annoksen. Muut koejäsenet saivat rikkiä vain kylvön AN:a sisältäneen lannoitteen (Yara Pellon Y6 15-7-13-3) mukana lukuun ottamatta käsittelyä, jossa rakeinen AS annettiin kylvölannoituksen yhteydessä. Siinä S-annos oli peräti $137 \mathrm{~kg} / \mathrm{ha}$.

Vuonna 2015 niissä koejäsenissä, joissa levitettiin AS:a nestemäisenä ennen kylvöä letkulevitystä imitoiden, AS:sta tulevaa N-määrää vähennettiin tasosta $60 \mathrm{~kg} / \mathrm{ha}$ tasoon $20 \mathrm{~kg} / \mathrm{ha}$, koska AS:sta tuleva S-määrä on 1,15-kertaa N-määrä, jolloin S-annos muodostuu kohtuuttoman suureksi N-määrän olleessa $60 \mathrm{~kg} /$ ha (taulukko 2). Liiallisella S-määrällä saattaa olla haitallisia vaikutuksia seleenin ottoon. AN:a käyttäen N-annos oli vuonna $201520 \mathrm{~kg}$ /ha tai 60 kg/ha. Näiden käsittelyiden N-määriä täydennettiin tasoon $120 \mathrm{~kg} / \mathrm{ha}$ kylvölannoituksen yhteydessä sijoitetulla AN:a sisältävällä lannoitteella. N-tasojen mukana ollut käsittely rakeisella AS:lla sai samaisen huomattavan S-annoksen kuin vuonna 2014.

Jokioisissa vuonna 2014 N-tasoissa ja AN-käsittelyissä käytetty rakeinen lannoite oli Yara Pellon Y6 (15-7-13-3). Perustyppitaso sai $120 \mathrm{~kg} \mathrm{~N} / \mathrm{ha}, 56 \mathrm{~kg} \mathrm{P} / \mathrm{ha}, 104 \mathrm{~kg} \mathrm{~K} / \mathrm{ha}$ ja $24 \mathrm{~kg}$ S/ha. ASliuokset valmistukseen käytettiin Yara Suomensalpietari (27-0-1-4) lannoitetta. Pellon Y6 ja Suomensalpietari sisälsivät seleeniä. Suomensalpietarista tuli ennen kylvöä tehdyn levityksen mukana 8,9 kg/ha ja tähkälle ruiskutettaessa 2,2 kg/ha rikkiä. AS-liuokset tehtiin Envorin AS-liuoksesta. Sen mukana tuli S:ä ennen kylvöä tehdyssä levityksessä $69 \mathrm{~kg} / \mathrm{ha}$ ja tähkälle ruiskutettaessa 17,25 kg/ha. Lisäksi näissä käsittelyissä rakeisen mineraalilannoitteen mukana tuli $12 \mathrm{~kg} \mathrm{~S} / \mathrm{ha}$. Urea liuos valmistettiin Yaran ureasta.

Yltöisissä vuonna 2015 N-tasoissa ja AN-käsittelyissä käytetty rakeinen lannoite oli Yara NPKS (27-2-3-2,5). Se ei sisältänyt seleeniä. Perustyppitaso sai $120 \mathrm{~kg}$ N/ha, 8,9 kg P/ha, 13,3 kg K/ha ja $11,1 \mathrm{~kg}$ S/ha. AN-liuokset valmistukseen käytettiin Yara NPKS (27-2-3-2,5) lannoitetta, joten sen Sannos oli sama kuin perustyppitasossa ennen kylvöä tehdyissä levityksissä. Tähkälle levityksen yhteydessä tuli 1,4 kg S/ha lisää. AS-liuokset tehtiin Envorin AS-liuoksesta. S-annokset niissä olivat $74,6 \mathrm{~kg} / \mathrm{ha}$ (60 kg N/ha) tai 32,3 kg/ha (20 kg N/ha) riippuen AS:n osuudesta N-lannoituksessa. Tähkälle ruiskuttaessa S-annos oli samainen 17,25 kg/ha kuin vuonna 2014.

Kylvön yhteydessä sijoitetun mineraalilannoitteen ammonium- ja nitraattitypen märä suhteet riippuvat lannoitteessa olevien negatiivisesti varautuneiden ravinteiden pitoisuuden mukaan. Vain N:ä sisältävissä rakeisissa lannoitteissa ammonium- ja nitraattityppeä on yhtä paljon. Jokioisissa Ntasoissa käytetyssä N-lannoitteessa nitraattitypen osuus oli 34 \% ja Yltöisissä käytetyn 45,2 \%. Yltöisissä käytetyssä lannoitteessa nitraattitypen osuus oli siten selvästi suurempi kuin Ojaisilla käytetyssä. Kun kasvukausi 2015 oli lisäksi varsin sateinen, suurempi osa lannoitteen N:Stä saattoi huuhtoutua vehnän ulottumattomiin kuin Ojaisilla.

Kasvukaudet olivat toistensa vastakohdat. Vuosi 2014 oli helteinen ja alkukesän sateet osuivat kohdalleen vehnän kasvun kannalta. Vuonna 2015 sateinen kevät viivytti kylvöjä, ja sateet jatkuivat koko kesän. Koealueen hidas kuivuminen ja jatkuvat sateet siirsivät vuoden 2015 kenttäkokeen perustamista varsin myöhäiseen ajankohtaan kesäkuun 2.viikolle. Sadesummien kertymät olivat varsin samanlainen vajaat 1,5 kuukautta kokeen perustamisesta kumpanakin vuonna. Vuonna 2014 heinäkuun alussa alkoi poutajakso, jolloin sadesumman kertymä oli hidasta sen sijaan vuonna 2015 sateita tuli tasaisesti ja sadesumma karkasi tämän jälkeen vuoden 2014 sadesumman kertymän edelle. Kasvustot olivat siihen mennessä kuitenkin kehittyneet siinä määrin, että ne haihduttivat vettä sellaisen määrän, että ainoastaan pienimmät N-tasot kärsivät maan märkyydestä.

Lämpösummien kertymä kokeen perustamisen jälkeen oli kumpanakin koevuotena varsin samanlainen. Vuonna 2015 perustaminen tapahtui kuitenkin 17 vrk myöhemmin kuin vuonna 2014. 
Tämä tarkoittaa 169 astetta tehoisan lämpösumman menetystä kasvukauden alusta vuoteen 2014 verraten. Wellamo -kevätvehnän lämpösummavaatimus on 1020 astetta. Vuonna 2014 koeruudut korjattiin, kun lämpösummaa oli kertynyt 1128 astetta. Kasvuajaksi muodostui vuonna 2014105 päivää, joka on 1,5 päivää nimellistä $(102,4)$ kasvuaikaa pitempi.

Vuonna 2014 nestemäinen AN tai AS 60 kg N/ha levitettiin ennen kylvöä 22.5. kastelukannuilla imitoiden letkulevitystä, jossa riviväli on $25 \mathrm{~cm}$. AN tai AS liuotettiin veteen ja laimennettiin vesimäärään, joka levitettynä vastasi noin $22 \mathrm{~m}^{3} /$ ha levitysmäärää. Tämä siksi, että näitä nesteitä olisi ollut mahdoton levittää tasaisesti kastelukannulla noin 10 metrin pituiseen koeruutuun, jos yhteen riviin levitettävä nestemäärä ei olisi ollut vähintään noin 10 l. Käytännön levitys voitaisiin tehdä esimerkiksi kasvinsuojeluruiskulla lannoitesuuttimilla pienempänäkin nestemääränä. Levitetyt tuotteet mullattiin noin tunnin kuluttua levityksestä joustopiikkiäkeellä koeruudun suuntaisesti. N-määrä nostettiin tavoitetasoon (120 kg N/ha) rakeisella AN:a sisältäneellä lannoitteella kylvölannoituksen yhteydessä.

Vuonna 2014 rikkakasvit torjuttiin 1.7. käyttäen torjuntaineita Atribut Sekator 60 g/ha ja Sekatoria $100 \mathrm{ml} / \mathrm{ha}$. Käytetty vesimäärä oli $200 \mathrm{l} / \mathrm{ha}$. Vuonna kasvitaudit torjuttiin 10.7. valmisteilla Moddus, Prosaro 0,4 l/ha ja Comet Pro 0,4 l/ha tankkiseoksena laon torjumiseksi annetun Modduksen 0,2 l/ha kanssa. Käytetty vesimäärä oli 200 l/ha. Vuoden 2014 lisälannoitukset (15 kg N/ha) AN: lla, AS: lla tai urealla tähkällä toteutettiin 6.8. koeruuturuiskulla nestemäärän olleessa 200 l/ha. Koeruudut puitiin 4.9., punnittiin.

Vuonna 2015 käytettiin vastaavia menetelmiä kuin vuonna 2014 kokeiden perustamisessa. Koe perustettiin 8.-9.6. Rikkakasvit torjuttiin 14.7. samoilla tehoaineilla kuin vuonna 2014. Lisäksi käytettiin kuitenkin MCPA-valmistetta koealuetta kiusanneen peltokortteen torjumiseksi 17.7. samalla torjuttiin lako, kuten 2014, mutta kasvitaudit jätettiin torjumatta tuleentumisen nopeuttamiseksi Koeruudut puitiin 28.9 .

\section{Tulokset ja tulosten tarkastelu}

Vuonna 2014 saavutettiin lannoittamatta normisato $1276 \mathrm{~kg} / \mathrm{ha}$ (kosteus 14 \%) (kuvio 4). Nlannoituksen kasvaessa sato kasvoi lähes lineaarisesti käytetylle tavoitetyppitasolle (120 kg N/ha) saakka ollen tällöin noin $5000 \mathrm{~kg} / \mathrm{ha}$. Satoa saatiin tuolla välillä lisää 29,3 kg/kg N. Näin ollen tulosten tulkinnan kannalta koejärjestely onnistui erinomaisesti. Tavoitetasoa suuremmilla $\mathrm{N}$-tasoilla sato ei juuri kasvanut. Ympäristökorvaus (VN 2015) sallii tällä satotasolla käytettäväksi koealueen multavalla maalla 140 kg/N ha. Näin ollen myös lisälannoituskäsittelyiden N-lannoitus 135 kg/ha oli ympäristökorvauksen rajoissa. Koska sato ei kasvanut tavoitetasoa suuremmilla $\mathrm{N}$-tasoilla, lisälannoituksista ei ollut odotettavissa satotason nousua lannoitusajankohdasta riippumatta, vaan kaikki sen ylittävä Nlannoitus lähtökohtaisesti saattoi vain nostaa sadon raakavalkuaispitoisuutta. Lisätypen käyttö jopa laski satoa suhteessa niiden jo kylvön yhteydessä saaman N:n tuottamaan. Vuonna 2015 vehnä tuotti vain $600 \mathrm{~kg} / \mathrm{ha}$ ilman lannoitusta. Tämä johtui siitä, että kasvukausi oli hyvin sateinen ja lannoittamaton kasvusto kehittyi hyvin hitaasti, ei pystynyt haihduttamaan sadannan tahdissa ja siten sen juuristo kärsi maan liiallisesta märkyydestä. Sato kasvoi lineaarisesti lannoittamattomasta aina typpitasolle 90 $\mathrm{kg} / \mathrm{ha}$ saakka. Satoa saatiin tällä välillä lisää $37,6 \mathrm{~kg} / \mathrm{kg}$ N. Sadon lineaarinen kasvu siten taittui ennen N-lannoituksen perustasoa $120 \mathrm{~kg} / \mathrm{ha}$. N-tasolla $90 \mathrm{~kg} / \mathrm{ha}$ saatiin olosuhteisiin nähden hyvä sato 3952 $\mathrm{kg} / \mathrm{ha}$. N-lannoituksen lisääminen tästä lisäsi vain vähän satoa $(6,24 \mathrm{~kg} / \mathrm{kg} \mathrm{N})$, mutta sato kuitenkin kasvoi aina korkeimmalle N-tasolle $180 \mathrm{~kg} /$ ha saakka. Sillä saatiin $4458 \mathrm{~kg} / \mathrm{ha}$ ja sato olisi todennäköisesti kasvanut N-lannoitusta edelleen tästä lisättäessä. Lisäsadon arvo yli $90 \mathrm{~kg}$ N/ha tasoilla ei kuitenkaan olisi kattanut edes lisätypen hintaa mineraalilannoitteen N:n hinnan mukaan laskettuna. Käännepiste N:n satovasteessa oli hyvin jyrkkä juuri $90 \mathrm{~kg}$ N/ha kohdalla. Näissä oloissa olisi ollut parempi, jos N-lannoituksen perustaso olisi ollut $90 \mathrm{~kg} / \mathrm{ha} 120 \mathrm{~kg} / \mathrm{ha}$ tason sijasta. Kylvön yhteydessä sijoitettuna AS tuotti 2,9 \% paremman sadon kuin AN, vaikka sen mukana tullut S-annos (137 kg/ha) oli melkoinen eikä sen mukana tullut muita ravinteita. Suurestakaan S-annoksesta ei näyttänyt olevan haittaa sadonmuodostukselle. Se kuitenkin laski sadon seleenipitoisuutta. Sen käsittelyn, joka oli saanut AN:na $120 \mathrm{~kg}$ N/ha ja S:ä vain 11,1 kg/ha, sadon seleenipitoisuus oli $20 \mu \mathrm{g} / \mathrm{kg} \mathrm{ka}$. Sijaan AS:na saman N-määrän mutta $137 \mathrm{~kg}$ S/ha saaneen käsittelyn sadon Se-pitoisuus oli $16 \mu \mathrm{g} / \mathrm{kg} \mathrm{ka}$. Lannoitteissa ei ollut Se:ä, joten ero syntyi siten, että S haittaisi vehnän Se-ottoa maan Se-varoista. Satojen Se-pitoisuus oli kummassakin käsittelyssä hyvin pieni johtuen siitä, että lannoitteissa ei ollut Se:ä. 


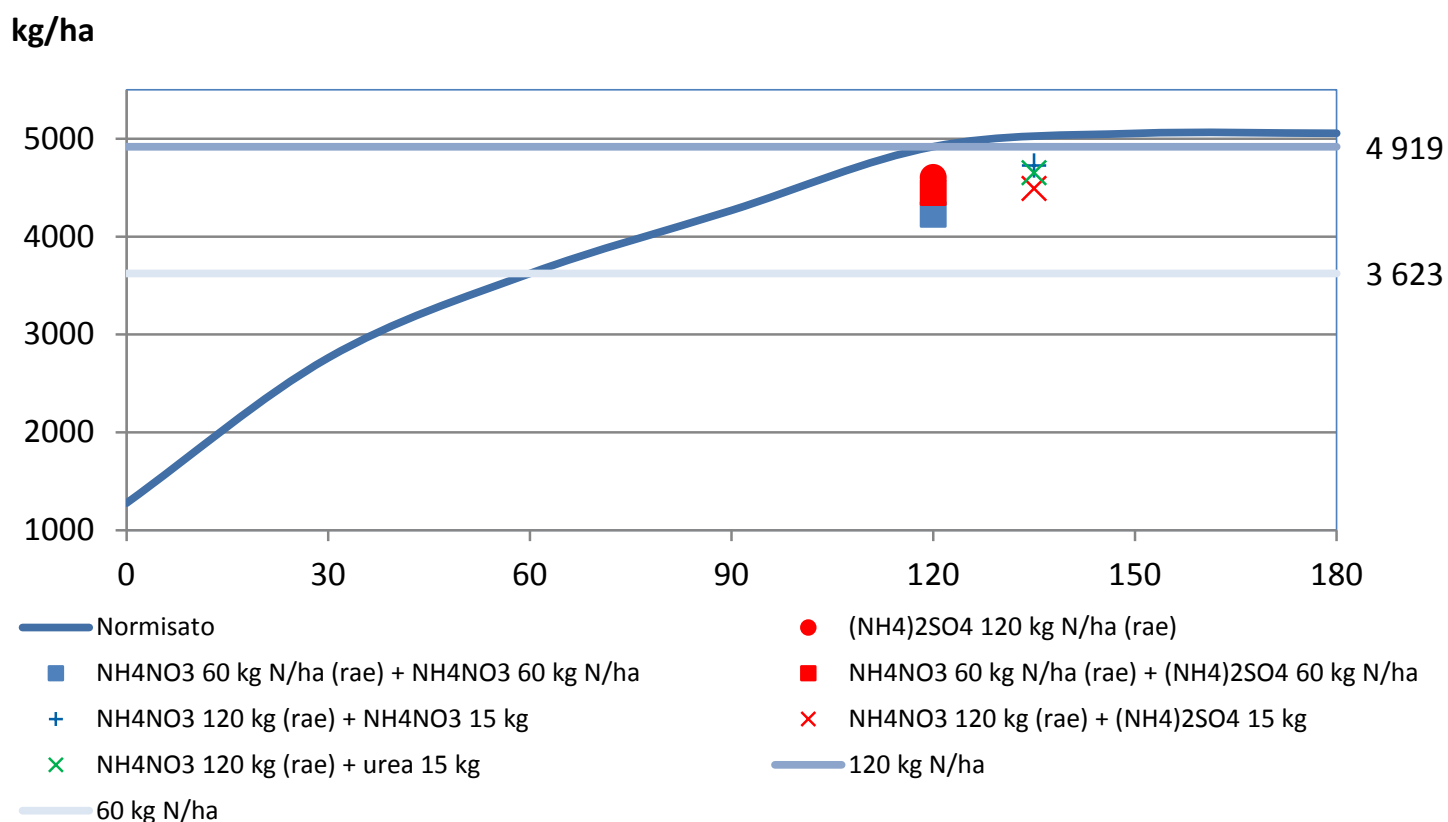

Kuvio 4. Normisato (RH 14 \%) vuonna 2014

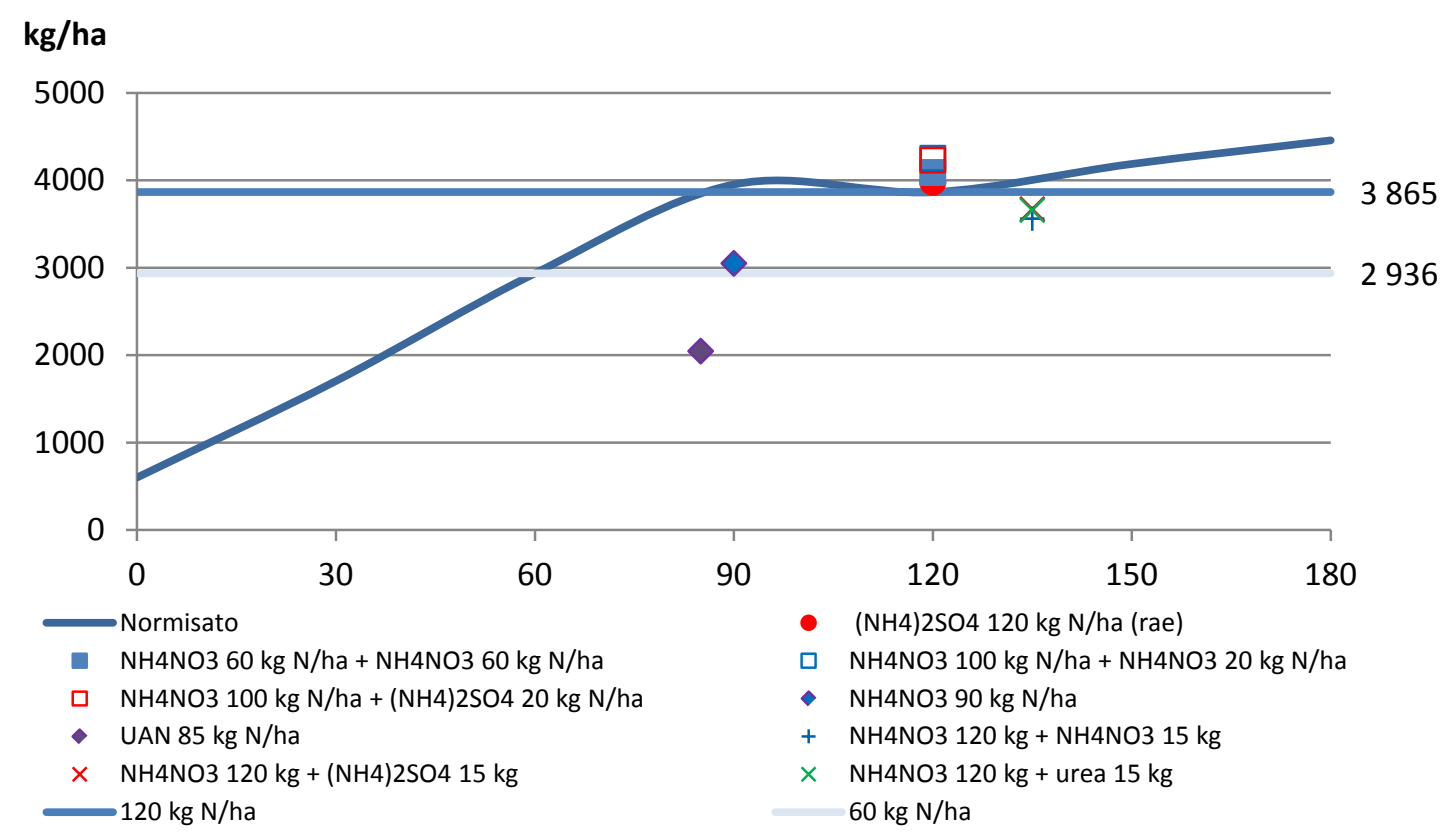

Kuvio 5. Normisato (RH 14 \%) vuonna 2015

Käsittelyt, joissa osa N:stä annettiin kastelukannulla ennen kylvö letkulevitystä matkien, tuottivat vähintään N-tasoaan vastaavat satotasot. AN näytti toimivan hieman AS:a paremmin, kun levitystapa imitoi letkulevitystä. Letkulevitetyllä AS:lla saatiin kuitenkin lähes yhtä suuri sadonlisä kuin AN:lla letkulevitetyn N-määrän ollessa 20 kg/ha. Kummassakin tapauksessa sato oli 9,5 -10,1 \% suurempi kuin sijoitettaessa koko N-määrä kylvön yhteydessä. Sato vastasi satoa, joka saatiin sijoittamalla noin 165 kg N/ha kylvön yhteydessä. Kun kylvön yhteydessä sijoitettiin rakeista AS:a 120 kg N/ha, sato oli hyvin vähän suurempi kuin vastaava määrä AN:a sijoittamalla. AN ja AS:n välinen ero ei ole tässä kohdassa merkittävä. Tulosten perusteella näyttäisi kuitenkin ilmeiseltä, että osan N:stä sekoittamalla multaamalla muokkauskerrokseen, oli vuoden 2015 kasvukaudessa eduksi. Ilmeisesti muokkausker- 
rokseen sekoitettu $\mathrm{N}$ tavalla tai toisella säilyi paremmin vehnän käytettävissä. Kasvikausi oli sateinen myös maan märkyyden takia myöhään tehdyn kylvön jälkeen, joten N:n jäämisestä muokkauskerrokseen ei näissä oloissa ollut haitta, vaan pikemminkin hyötyä, joka ei välttämättä toteudu normaalimpana kasvukautena. Käytettyä 20 kg N/ha vastaava nestemäärä vastaa esimerkiksi kasvinsuojeluruiskulla ennen kylvöä potentiaalisesti glyfosaatin kanssa tankkiseoksena annettavaa määrää. Tosin kylvötapa olisi tällöin potentiaalisesti suorakylvö, ja ruiskulla annettuna vaikutus pienenä nestemäärä voisi olla erilainen. Ruiskulla levitetään noin $200 \mathrm{l} / \mathrm{ha}$ ja letkulevityksessä määrä oli noin 16,7 m³/ha.

Suorakylvökoneella kylvetystä vehnästä ei saatu N-tasoa vastaavia satoja edes mineraalilannoitteella. Satotaso vastasi vain N-tason noin $60 \mathrm{~kg} / \mathrm{ha}$ satotasoa perinteisellä kylvölannoittimella kylvetyssä vehnässä, vaikka käytetty N-taso oli $90 \mathrm{~kg} / \mathrm{ha}$. Suorakylvökone ei soveltunut tilanteeseen, jossa sillä kylvettiin peltoon, joka oli kylvömuokattu perinteistä kylvötapaa varten. Nestemäinen lannoite sijoitettuna suorakylvökoneella kylvön yhteydessä tuotti sadon, joka vastasi noin $40 \mathrm{~kg} / \mathrm{ha} \mathrm{N}$ lannoitusta perinteisellä kylvölannoittimella kylvön yhteydessä sijoitettuna. Nestemäisen lannoitteen käyttö alensi satoa suhteessa rakeisen mineraalilannoitteen käyttöön vastaavalla kylvömenetelmällä. Tähkimisvaiheessa 15 kg/ha lisätyppeä saaneiden käsittelyiden satovaste oli erikoinen. Sato oli pienempi kuin ilman lisälannoitusta olisi pitänyt saada.

\section{Johtopäätökset}

Koevuosien kasvukaudet edustivat pitkälti ääripäitä sääolosuhteiltaan, joten tulokset kattavat potentiaaliset kasvukaudet. Sateinen vuosi 2015 oli edullinen runsaalle ammoniumtypen osuudella Nlannoituksessa. Lantaperäiset strippaustuotteet ovat potentiaalisesti AS-lannoitteita, jolloin ne sopivat erityisesti olosuhteisiin, joissa kasvukausi on sateinen ja typen huuhtoutumisen vähentämiseksi ammoniumtypen suuri osuus on etu. Ne sopivat huonommin normaaliin kuivan alkukasvukauden olosuhteisiin, joissa typen helppo saatavuus on etu. AS:ssa S-määrä on suhteeton suhteessa N-määrään. Vaikka suuri S-määrä ei sinällään näytä olevan haitaksi sadonmuodostukselle, sen suuri määrä vähentää kasvien Se-ottoa maasta ja lannoitteesta. Se puolestaan johtaa siihen, että sadon Se-pitoisuus laskee. Vaikka kasvit eivät itse kärsi Se-puutteesta, niistä valmistettuja tuotteita syövät tuotantoeläimet ja ihmiset kärsivät. Se:ä lisätään lannoitteisiin juuri rehujen ja kasvisruuan Se-pitoisuuden kohottamiseksi. Se:ä ei voida lisätä rehuihin ja ruokiin, koska sen yliannostus on vaaraksi terveydellä. Maata käytetään sopivana puskurina. Tämän vuoksi AS-osuus N-lannoituksessa pitäisi rajoittaa noin $20-30$ $\mathrm{kg} / \mathrm{ha}$. Lantapohjaisten strippaustuotteiden laajempi käyttö edellyttäisi sitä, että pesu tehdään typpihapolla, jotta typpi olisi AN-muodossa. AS-muodossa olevan N- osuus voisi siten olla noin 20 - 30 \%. Tällöin S-lannoitus olisi sopiva. Typpihappo on kuitenkin kalliimpaa kuin rikkihappo ja AN:n valmistukseen liittyy mm. räjähdysriski.

Nestemäisellä AS:lla ei saavutettu mitään erityisetuja. Se sopi huonosti käyttöön tähkimisvaiheessa. Se voisi sopia käytettäväksi ennen kylvöä juolavehnän torjunnan yhteydessä suorakylvöpelloilta tankkiseoksena glyfosaatin kanssa. Lisäksi se voisi sopia käytettäväksi rikkakasviruiskutusten yhteydessä vastaavalla tavalla. Tällöin tankkiseosten tekninen toimivuus ja vaikutus torjuntatehoon pitäisi selvittää erikseen eri torjunta-aineille, mikä on jatkotutkimuksen aihe. Lisäksi käyttö suorakylvöön liittyen vaatii jatkotutkimuksia.

Lantaperäisen AS:ssa N:n ja S:n hinta ei voi olla suurempi kuin näiden ravinteiden markkinahinta. Myöskään lantaperäisten lannoitteiden muodosta ei ole etua. Vastaavia lannoitteita on yleisesti saatavilla markkinoilla näiden ravinteiden yleisellä hintatasolla, jopa edullisemmin.

\section{Kirjallisuus}

VN 2014. Valtioneuvoston asetus eräiden maa- ja puutarhataloudesta peräisin olevien päästöjen rajoittamisesta 1250. Annettu Helsingissä 18.12.2014.

VN 2015. Valtioneuvoston asetus ympäristökorvauksesta 235. Annettu Helsingissä 19. maaliskuuta 2015. 